\title{
Golden year
}

\author{
The gift of memories.
}

\section{Igor Teper}

It was only when Will found himself among the poplars, maples and oaks of a grove in Aventine Habitat's eastern park that he figured out why he'd felt so antsy all morning. Why he was so restless that he'd decided to defy the aches and lethargy that were now his constant companions, to leave his room for the first time in weeks and go for a long walk through the habitat. Only when his legs, as if hearkening back to his younger days, had brought him to stand among those wellremembered trees did he realize that this would have been the day of his fiftieth wedding anniversary.

Alice had modelled the grove on the clearing in the Maine woods where he had proposed to her, during a hike on a brisk October afternoon more than half a century before. The inspiration for the grove's design had been their secret, and they had come there for every anniversary after they moved to the Moon - 36 anniversaries in all. The memory of those visits was a time-lapse film of the trees' growth, from seedlings to saplings to giants that now almost completely blocked the artificial daylight streaming down from the underside of the habitat's dome.

Alice's hortisculptures were all over the habitat. Trees moulded by both their genes and the ecomaintenance programs that controlled the temperature, humidity, lighting and soilnutrient content so that they bent and intertwined as they grew to form domed enclosures, gazebos and arches, or twisted into helices and braids, or lifted and drooped their branches into fountains and waterfalls of leaves.

But it was the grove, simpler and quieter than her other creations, and more private, that had been Alice and Will's special place. For a long time after Alice received the offer from Aventine Habitat, Will had resisted the idea of moving to the Moon. He had not wanted to abandon the life they'd started to build in the place where he'd lived all his life. In the end, he acquiesced, and to thank him for giving her the opportunity to shape the greenery of an entire city, Alice had used her singular talents to recreate a piece of the New England he missed so intensely.

As he saw the grove take shape over the years, Will had been amazed at the faithfulness of the reproduction. It not only looked but, on a visceral level, felt like the spot where he'd pretended to trip and met Alice's concern with a ring and a question.

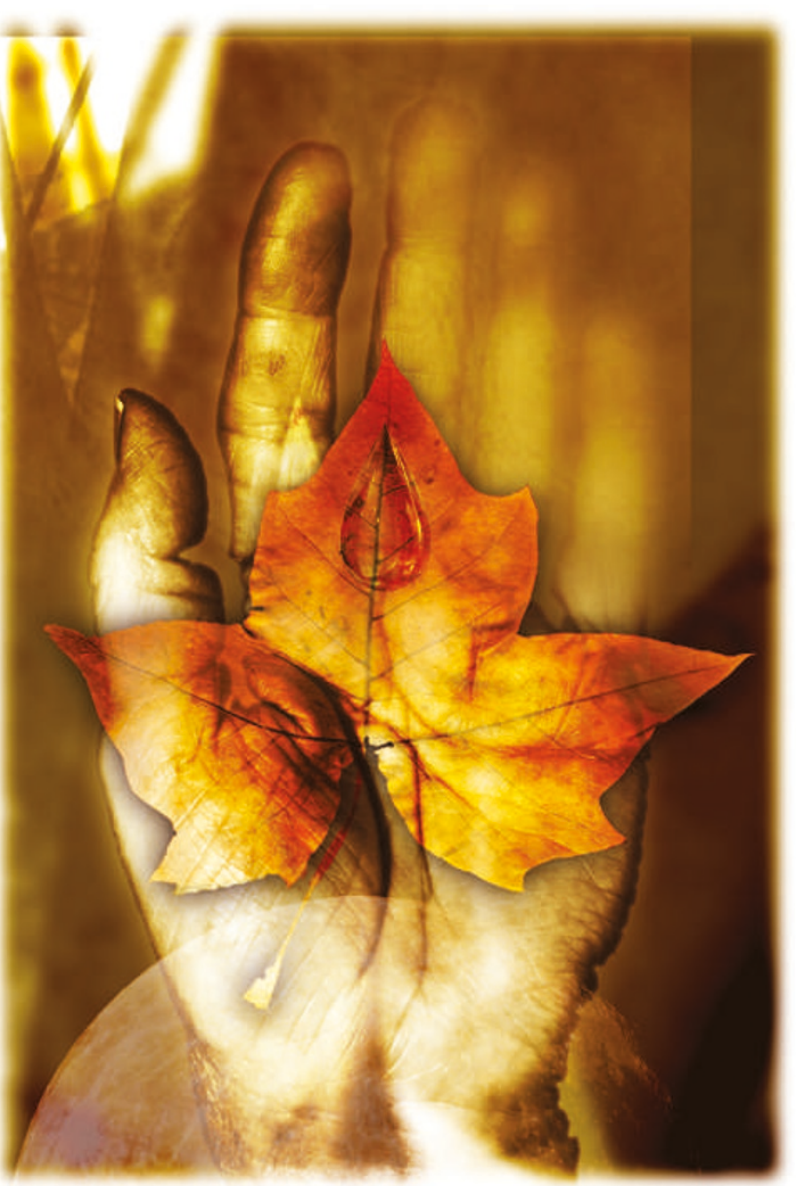

The only difference was that, when he'd proposed, the trees had been alight with the most brilliant golds and crimsons of autumn, whereas the leaves in the seasonless habitat were always green. He'd once pointed this out to Alice, and she'd turned silent and looked away. He never mentioned it again.

Will had not returned to the grove since Alice's fatal illness, six years earlier, and it was now more like his memory than ever, a living bridge through time and space. It was as if Alice herself were reaching to him from the past, so close he could touch her.

He pressed his hand to the trunk of one of the largest maples, and was struck by how much the bark, grey and brown, with light streaks and dark spots, looked like the age-mottled skin on the back of his hand. It occurred to him that even as the trees had grown into what they'd been meant to be, he had decayed far from the man Alice had agreed to marry.

He closed his eyes; the bark was warm and leathery beneath his fingers. A cool breeze caressed the back of his neck, and the ground seemed to shift beneath his feet. Leaves rustled overhead, and the air was filled with a scent so familiar it was unrecognizable. And with that scent, the memory of Alice looking down at him as he knelt before her that day in Maine flooded his senses, unbearably intense. Will opened his eyes, and did not believe them.

Gold, bronze, copper, amber, carnelians and rubies - the trees around him blazed with the most majestic display of autumn colours he'd ever seen, a swirling kaleidoscope that glowed and burned and sparkled. Face raised, mouth open in astonishment, he stepped back from the maple and slowly turned, trying to take in the entire scene, every tree, every branch, every leaf.

He could not begin to imagine what miracles of genetics and biochemistry had made the trees' transformation possible at his touch, but, for their golden wedding anniversary, Alice had given him autumn. She had prepared it all those decades ago, and had never, not even when she lay dying, given him any hints of what she'd planned. Still, some part of him must have known, for he had come to receive his gift, or perhaps she had known him so well that she'd foreseen his coming.

Will's heart, and his throat, and his thoughts seized up then; he missed Alice more acutely than he ever had, and he loved her more deeply than ever. Tears came pouring from within him, hot tears that watered the soil where Alice had planted her love, and, as he cried, leaves began to fall around him, like tears of gold.

Igor Teper teaches old atoms new tricks at temperatures just above absolute zero. He also writes stories, occasionally. 